\title{
The Effect of Internal Marketing on Organizational Citizenship Behavior an Applicable Study on the University of Jordan Employees
}

\author{
Muhammad Alshurideh ${ }^{1}$, Anas Y. Alhadid ${ }^{2} \&$ Alkurdi Barween ${ }^{3}$ \\ ${ }^{1}$ Head of Marketing Department, The School of Business, The University of Jordan, Amman, Jordan \\ ${ }^{2}$ Head of Marketing Department, Applied Science private University, Amman, Jordan \\ ${ }^{3}$ Part time Lecturer, The School of Business, The University of Jordan University, Amman, Jordan \\ Correspondence: Muhammad Alshurideh1, The School of Business, The University of Jordan, Amman 11942, \\ Jordan. Tel: 962-6-535-5000 ext. 24255. E-mail: m.alshurideh@ju.edu.jo
}

Received: November 29, 2014

Accepted: December 30, 2014 Online Published: January 26, 2015

doi:10.5539/ijms.v7n1p138

URL: http://dx.doi.org/10.5539/ijms.v7n1p138

\begin{abstract}
A tremendous shifting of businesses at the present time forced organizations to live in a dynamic, ambiguous, and changeable environment. Due to these challenges, organizations need to apply the new marketing orientation that enhance businesses; and improve their businesses permanently to keep their competitive excellence. One of the main important factors to consider is by attracting new customers and maintaining healthy long-term relationship with them. This cannot be accomplished without improving the organizational performance through-out applying the internal marketing concepts which can be translated as seeing its employees as its first market (Sinčić \& Vokić, 2007).

This paper discusses and investigates the effect of a set of internal marketing elements such as employees' motivation, communication, empowerment, and training on organizational citizenship behavior. The quantitative data collection approach is used to collect the suitable data from a sample of 300 fulltime employees. Results have explored new routes in how organizations can create, maintain, and enhance organizations' citizen behavior. Which indicate, that there is a positive relationship between internal marketing dimensions; and organizational citizenship behavior in varying magnitude. Furthermore, the investigation showed that the dominant dimension of internal marketing is the motivation; then followed by the communication with stronger impact on organizational citizenship behavior, where the surprising results that the empowerment; and training and development don't have that much effect. Also, hypotheses were tested, and more information regarding data analysis, results' discussion and study limitations were presented in more details.
\end{abstract}

Keywords: internal marketing, organizational citizenship behavior, motivation, communication, empowerment, training

\section{Introduction}

At the present time, organizations live in a dynamic, ambiguous, and changeable environment. Due to these dynamics new challenges faces organizations, the new orientation to improve their performance permanently to keep their competitive excellence; one of the most important factor to maintain, and attract new customers, is improving the organizational performance through the internal marketing concept; which considered a significant activity in the development of the employees, as internal customers of the organization; while the main purpose is extending the awareness from internal customers, and removing the obstacles in the direction of organizational effectiveness.

This paper seeks to explore the effect of internal marketing on organizational citizenship behavior. According to Sinčić and Vokić (2007) internal marketing views its employees as its first market. It is not limited to frontline customer's service alone; it also includes employees who do not interact directly with customers. Where Vasconcelos (2007) argues that, only when organization develops internal marketing strategies can be able to improve on external marketing strategies; also concentrating on the willingness to sell internal product to its internal customers will meet organization objectives. Many scholars such as Al-Hawary et al. (2013) and Podaskoff et al. (2000) emphasize that internal marketing influences organizational citizenship behavior. It is therefore worth noting that an organization should invest in internally for it to realize the benefits of extra- role 
behaviors.

\section{Literature Review and Research Hypotheses}

\subsection{Internal Marketing and Organization Citizenship Behaviour}

According to Barzoki and Ghujali (2013); Abzari and Ghujali (2011); one of the major factors that help in gaining a competitive advantage, and create sustainable value for an organizations is caring of human capital. Accordingly, providing human resources needs in each organization should be considered as the primary reason for final success of any organization. Due to that internal marketing is an approach which treat employees as most valuable asset; internal customers of organization and states that by satisfying internal customer's needs, organization situation will be in better; for offering services to external customers.

Marketing emphasizes on clients, partners and the society as large, the core to focus on the employees, so the internal marketing has been defined by different scholars as Gronroos (1981); Joseph (1996); Anselmo (2008) defined it as "Selling the firm to its employees", "as satisfying the employees' needs by supporting and offering a good atmosphere to increase the employee's satisfaction". Effective internal marketing responds to employee needs as it advances the organization mission and goals. Therefore, many scholars such as Aeeni et al. (2013), Gonza'lez and Garazo (2006), Prevail and Rafeq (2003) agreed that the internal marketing is concerned with helping the employees; to become more committed and motivated to the organization, and to retain the qualified employees, considering the employees in an organization as the internal market. It includes the ability of being able to convince employees to work together for the success of the organization. This eventually helps to meet the customer's need at the desired levels. This is guaranteed by improving quality of performance of human resources of the organization, especially in service providing institutions. According to Al-Hawary et al. (2013), for any organization to achieve success, it is important for it; to search its employees' needs and try to satisfy them. Aeeni et al. (2013) argued that it is easier to satisfy customers while having satisfied employees. ElSamen and Alshurideh (2012) also clarified that an organization should aim to make its internal customers appreciate its brand, and by doing so, its external customers will appreciate it as well. Therefore, following that, the employee needs are considered first before those of the customer.

Regarding the relationship between internal marketing, and organization citizen ship behaviour, many scholars have examined; and stated that there is a relationship existed between internal marketing and organizational behavior. According to Berryand, and Parasuraman (1991 cited Abzrri and Ghujali, 2011) internal marketing is defined as that process of attracting, and retaining employees. This normally is done through taking into consideration, the interests of employees first before those of the consumers. In addition, Souchon and Lings (2001) stated that the adoption of internal marketing practices and techniques has an effect on citizenship behavior and employee retention. This improves their in-role and extra role behaviors (Javadin et al., 2010). Bansal et al. (2001 cited Abzari and Ghujali (2011) argued that internal marketing influences organizational citizenship behavior which eventually has an impact on performance of the organization in total.

One of the modern concepts in the business environments is the organizational behavior; which refers to employees work behavior that engages in; besides the duties outlined in their job description, in which all are also termed as extra-role behaviors. According to Organ (1988), employees behaviors which represents in total the organization behaviour are usually not among organizational formal tasks, employees who engage in organizational citizenship behavior are those that work beyond levels required to get a satisfactory job.

Employees who engage in organizational citizenship behavior, may not be directly rewarded by the organization, but may benefit from outstanding performance appraisal. Organ et al. (2006) emphasized that employees usually exhibit their citizenship behaviors based on their ability, motivation; in addition to what level do they contribute positively to the organization (Organ, 1988). What are the main dimensions of organization citizenship behaviour? Large number of scholars has identified different set of dimensions. For example, Podskoff et al. (2000) identified many dimensions for organizational citizenship behavior which are: sportsmanship, civic virtue, self-development, individual initiative, helping behavior, and organization compliance, and organization loyalty. Also, Natemeyer (1997) mentioned that organizational citizenship main dimensions are: altruism, civic virtue, sportsmanship and conscientiousness. Altruism, can be defined as the behavior exhibited through voluntarily helping other less experienced employees, or even those that have not completed their assignment according to (Abzari and Ghujali, 2011). Moreover, MacKenzie et al. (1998) referred to it as the helping behavior towards other employees to accomplish their tasks in abnormal organizational conditions. This voluntary helping behavior usually prevents work related problems. In addition, civic virtue is described as the internal attitude toward the organization; and how much the employee takes on his responsibility to show good image about the organization that he works for and also to what level does he take cares of organizational life (Organ et al., 2006). 
Also, civic virtue refers to commitment to the organization by demonstrating the willingness to be actively involved in its activities such as attend meetings; and extra work that is not included in their job description or out of their working hours, reading different books and magazines in addition to attend training courses just to enhance their public information (Organ, 1988). It also entails having the organizations best interests at heart which can be achieved by identifying its opportunities, and threats (Podsakoff et al., 2000). What's more, sportsmanship can be stated as how much the employees can bear or stand the workplace environment without "complaining ... and making a federal case out of small potatoes" (Organ, 1988, p. 11 as cited in at Kernodel, 2007). Besides, Abzari and Ghujali (2011) defined sportsmanship as the ability of an individual to adapt to a working place; without any objection despite the inevitable impositions plus its ethical and polite behaviors towards others and it has everything to do with tolerance. Podsakoff et al. (2000) further said that not taking offence even when inconvenienced by others or even when they do not buy your suggestions and opinions is true sportsmanship. At the end, conscientiousness is one type of behaviors that is referred to organizational compliance. Graham (1991) referred to it as organizational obedience, this dimension entails personal acceptance of rules and regulations in an organization and complying with them. Podaskoff et al. (2000) claimed that employees who comply with organizational procedures therefore should work even when under no supervision.

In addition, according to Hog et al. (1998) as cited by Al-Hawary et al. (2012), there are a set of internal marketing dimensions which are: motivation, communication, empowerment, training and development. While ElSamen and Alshurideh (2012) stated that internal marketing dimensions are: motivation, communication, employee selection, recruitment and development, work environment and support system. Within the same theme, Liylod (2004) outlined that internal marketing entails but is not limited to communication, recognition and orientation and training. Also, Ching and HsinHsin (2007) implied that the five aspects of internal marketing are: training of employees, communication (both internal and external), administrative support, human resource management and development. Based on reviewing the literature, this study is planned to take deep insight into a set of factors that seen core stones in creating and developing organization citizenship behaviour which are: motivation, communication, empowerment, and training and development. The next section provides more lights on explaining each factor separately.

\subsection{Motivation}

In this paper the first element to be examined is motivation, it considered the major factor that has a huge impact on the employee's productivity and behavior; so managers should understand how to motivate the employees to enhance their performance, motivation is the drive to act or behave in a certain way (Herzberg, 1968; Bigley \& Steers, 2003). It is "the movement of workers to act in a desired manner" (Mark et al., 1998), at the organizational level, the managers can motivate the employees through appraisals, recognition and rewards. There is a difference between rewards, and wages, as the reward is received for an effective superior performance, and the wages is received for conducting the normal duties that are asked from the employees at a normal standard level (Saadat, 2005).

A study by Sangmook (2006) is designed to investigate whether the distinct classes of organizational citizenship behavior (OCB) such as generalized compliance and altruism can be found within the Korean public sector context, and whether public service motivation, organizational commitment and job satisfaction are drivers of OCB in Korean civil servants. The results showed that public service motivations seem to seen as a more significant predictor of OCB and it contributed more to enhancing the meaningfulness and applicability of the concept of OCB within the public sector of Korea. Moreover, Conway (2002 cited by Eldeen \& El-Said, 2001) emphasized on the importance of establishing motivation structures to enhance employee behavior and performance which in turn will be reflected on the organization overall performance. When the employees feel that their good performance earns rewards, productivity will be enhanced, turnover ratio and absenteeism will be decreased, group work will be more coordinated, and their resistance for change will be less. Eventually, employee cooperation towards achieving the organization's objectives will be obvious. Based on above explanation, the motivation effect can be translated as:

H1: There is a statistically significant effect of motivation on organizational citizenship behavior.

\subsection{Communication}

According to Aeeni et al. (2013), the manner of applying of communicative mechanisms is important in order to enhance knowledge, skill and awareness of employees from issues related to their jobs. The means through which information is conveyed from one party to the other is referred to as communication. Dramatically, the importance to disseminate relevant information to all employees in an organization so as to have common goals and values. Proper communication facilitates coordination of efforts towards achieving a common goal. The 
most effective method is face-to-face; however, internal communications also seek to improve employee relations with each other (Piercy \& Morgan, 1991). Also, according to Ahmed and Rafiq (2003), the major factor that facilitates the organizational change process is communication. Where Galpin (1997) ascertain the importance of communication to measure the internal marketing; which includes the management style in providing information to its employees, facing any difficulties in performing tasks, employees know to whom they will report. In addition, Dirks and Ferrin (2002) have confirmed the relationship between communication-feedback effects on organization behaviour. Result showed that trust and communication of performance are important and appraisal information which in-turn plays an essential role on creating suitable feedbacks that might raise both levels of performance, and job satisfaction. Communications approaches and ways in any organization may vary while the main point is not by discussing such approaches; but in how an organization should has the ability to communicate its values, and strategic points that fit accurately to their employees, and can be acknowledge smoothly (Deckop et al., 1999). Based on above clarification, the communication effect can be translated as:

$\mathrm{H} 2$ : There is a statistically significant effect of communication on organizational citizenship behavior.

\subsection{Empowerment}

McCoy and Associates (2006) defined empowerment as: "The authority and ability to take independent action, within well-defined parameters, which will actively influence the outcome". A clear description for empowerment has been provided by Greer and Melvin in (1994) as it is the process when the employees try to enhance their skills and abilities to improve themselves and also to find solutions for their problems. Empowering, means the process of decentralize the decision making, when employees are empowered; they are charged with the responsibility of whatever their actions may be. Empowerment usually accelerates the knowledge that is linked between work, and skills which have an influence on the motivation. Many scholars such as Boglera \& Somech (2004) and Shahin et al. (2014) emphasized that empowerment practices have considerable impact on the organizational citizenship behavior. In a study that have been done by Jha (2014) about the determinants of organizational citizenship behavior giving more considerations into both transformational leadership, and psychological empowerment; by collecting data from different five-stars hotel employees. The study found practical proofs that there are significant effects for both transformational leadership and psychological empowerment on organizational citizenship behavior (OCB). This study highlights the importance of giving more attention to the OCB antecedents especially the psychological ones which can be enhanced by executing several training programs, and bringing cultural changes. Based on above explanation, empowerment effect can be drawn as:

H3: There is a statistically significant effect of empowerment on organizational citizenship behavior.

\subsection{Training and Development}

According to Al-Hawary et al. (2013), training is defined as the acquisition of skills and attitudes required to perform specific tasks. An organization should be able to make new employees have the feeling that they have been hired due to their competence and experience (Liyold, 2011). The employees should be trained and developed in such way that they get to understand the organization's objectives so that they can handle the tasks delegated to them quite perfectly. This cannot be happen without having a healthy work environment which helps in facilitating initiatives, and acquiring effective managers throughout the world (Dowling \& Welch, 2004; Drost et al., 2002; Schuler et al., 1993). However, as Adler and Bartholomew (1992) have suggested, organizational strategy (the what) is becoming increasingly international faster than its implementation (the how) and much faster than the development of international managers (the who). International training and development can be seen as one of most crucial activities and the potential benefits of effective training and development are widely acknowledged (Dowling \& Welch, 2004). Training aims to improve current work skills and behavior, whereas development aims to increase abilities in relation to some future position or job, usually a managerial one (Dowling \& Welch, 2004). Within the same line, Caligiuri et al. (2001) emphasized that there is an association between met employee expectation and provision of training. They stated that highly relevant cross! Cultural training for example creates either accurate expectations or expectations of real difficulty prior to the assignment. To add more, Baumgarten (1995) suggested that since a training course of very short duration and climate development just prior to departure cannot be effective in changing and/or developing competencies related to attitudes, abilities or personality traits, a phased and cumulative approach be undertaken. Based on above clarification, the Training and development effect can be translated as:

H4: There is a statistically significant effect of training and development on organizational citizenship behavior. 


\section{Methodology}

To examine the study hypotheses, data have been collected using a survey method. The research population included all University of Jordan employees who are active in their positions related to the different management levels that they usually occupy in addition to teaching staffs who took managerial roles. Self-administrated questionnaires were handled to a random sample of 300 respondents, 200 of which were collected back, noting that 18 questionnaires were excluded because of their inadequacy for statistical analysis (incomplete or same answer to all questions), which in turn reduced the number of respondents to be used in the analysis stage. Therefore, the effective response rate in this study was $60.6 \%$, such rate is considered high and can be explained by the delivery method of the questionnaire bearing in mind that the researchers tried to minimize their contact with respondents during data collection stage to reduce the effect of respondents' bias. The questionnaire was developed in a set of stages. First, exploring the literatures in order to specify the variables, and their measuring items/scales, this resulted in developing the preliminary questionnaire which was presented in later stage to a few of academic scholars who gave essential feedbacks about it. After that, a pilot study was performed by disseminating questionnaires to a convenience sample. The questionnaire consisted of both closed-end questions. 5 point Likert scale of extremity ranging from 1, 'strongly disagree' to 5, 'Strongly Agree' was used for all survey items. Reliability of the scales was examined using Cronbach alpha. Concerning validity, all items that were used were gathered from established literature (e.g., Moosmayer \& Fuljahn, 2010; Varnali et al., 2012). Different descriptive and inferential statistical techniques were used to examine the data, descriptive statistics to identify the characteristics of the population, while inferential statistics were used to test research hypotheses. In more details, relationships between internal marketing elements and organizational citizenship behavior were examined separately using correlation analysis; to identify the relationships among study items' strengths and directions. More importantly, multiple regression analysis was used to identify which of study elements has the strongest relationship with organizational citizenship behavior.

\section{Findings, Hypotheses Testing and Discussion}

The results showed that $66 \%$ of respondents were females while the rest are males. More than half of the respondents' ages (52\%) were distributed between 25 and 35 years. Besides, about $40 \%$ of respondents were holding bachelor degrees. With regards to reliability, the Cronbach Alpha coefficient for each study item was examined and the reliability coefficients' results of all study variables were above the cutoff point of alpha (motivation $83 \%$, empowerment $77 \%$, communication $55 \%$, and both training and development $88 \%$ ). The correlation analysis test was also done for the study factors. Results show that the correlations values have come within the acceptance level above of $30 \%$ and less than $90 \%$.

Multiple Regression analysis has been used to test the study hypotheses. According to table number (1) in the next page, results showed that both motivation and communication had significant relationships with organizational citizenship behavior at 0.00 levels, with motivation having the biggest impact. However both empowerment and training analysis results showed not significant effect at .05 levels. Based on these results, the first and the second hypotheses are supported while both the third and the fourth ones are not supported; details are provided in tables 1 and 2 below.

Table 1. A summary of the hypotheses testing results is provided

\begin{tabular}{|c|c|c|c|c|c|}
\hline \multirow{3}{*}{ Model } & \multirow{2}{*}{\multicolumn{2}{|c|}{$\begin{array}{l}\text { Unstandardized } \\
\text { Coefficients }\end{array}$}} & \multirow{3}{*}{$\begin{array}{l}\text { Standardized } \\
\text { Coefficients } \\
\text { Beta } \\
\end{array}$} & \multirow{3}{*}{$\mathrm{t}$} & \multirow{3}{*}{ Sig. } \\
\hline & & & & & \\
\hline & $\mathrm{B}$ & Std. Error & & & \\
\hline (Constant) & 3.035 & .184 & & 16.491 & .000 \\
\hline F1- INDP V & .126 & .065 & .189 & 1.953 & .052 \\
\hline F2- INDP V & .107 & .054 & .170 & 1.965 & .051 \\
\hline F3- INDP V & $-.050-$ & .057 & $-.074-$ & $-.886-$ & .377 \\
\hline F4 & .041 & .071 & .058 & .578 & .564 \\
\hline
\end{tabular}

a. Dependent Variable: F5-Dep Var.

Table 2. Hypotheses testing results

\begin{tabular}{|c|c|}
\hline Hypothesis & Result \\
\hline H1: There is a statistically significant effect of motivation on organizational citizenship behavior & Supported \\
\hline $\mathrm{H} 2$ : There is a statistically significant effect of communication on organizational citizenship behavior & Supported \\
\hline H3: There is a statistically significant effect empowerment on organizational citizenship behavior & Not supported \\
\hline H4: There is a statistically significant effect training and development on organizational citizenship behavior & Not supported \\
\hline
\end{tabular}


As seen in the above tables, the effect of motivation element on employees' behavior has been approved. While motivation is not just considered one of the major factor that affect employees' behavior and productivity but it also drive their performance and empower them to act in a certain way in addition to goal setting and multiple task issues (Locke \& Latham, 2002). Thus, designing a fair motivation structure that suit driving an organization performance and achieving its goals that applied fully by managers who prefer to acknowledge such structure. To add more, Lin (2007) found that both extrinsic and intrinsic motivations affect employee knowledge sharing. Regarding the communication factor, as mentioned by Aeeni and et al. (2013), the manner of applying of communicative mechanisms is essential in order to enhance employees' knowledge, awareness and skills that related to their jobs. Thus, proper communication facilitates and coordination employees' efforts towards achieving well prepared an organization's goals. Not just that, some scholars found that internal communications seek to improve employees' relations with each other (Piercy \& Morgan, 1991) and effective internal communication usually improve both customer; and employees internal orientations towards achieving organization's goals (Conduit \& Mavondo, 2001).

\section{Conclusion and Implications}

The findings of this study confirmed the expected relationships between internal marketing elements; and organizational citizenship behavior. Concerning the strength of relationships, motivation activities had the strongest explanatory power/impact as suggested by Beta coefficient, this was followed by communication. Overall, internal marketing must be an essential part of the corporation's marketing plan; and must be integrated into the overall marketing strategy of any organization. From practitioner's perspective, it is suggested that corporations should adopt the concept of internal marketing that focus on providing a set of activities to increase the levels of organizational citizenship behavior. Moreover, marketers should take more care internal marketing activities, and direct more organizations' resources and capabilities towards benefiting their employee as much as possible. Through integrated marketing activities, In addition to focusing on empowerment, training and development activities, organizations should encourage tools that increase the citizenship behavior as it has become prevalent and widely famous among business environments In other words, more internal marketing trends should take place.

This study provides essential insights into internal marketing and organizational citizenship behavior. However, results and conclusions must be put in the context of the potential limitation, and directions for future research. In brief, this study was conducted with the selected elements of internal marketing. Therefore, future studies might consider other internal marketing elements on other business sectors It will also be interesting to get managers/decision makers views on the role of internal marketing using qualitative methods. Applying the research in different research settings should reinforce the generalizability of the results.

\section{References}

Abzari, M., \& Ghujali, T. (2011). Examining The Impact Of Internal Marketing On Organizational Citizenship Behaviour. International Journal Of Marketing Studies, 3(4), 1-11. http://dx.doi.org/10.5539/ijms.v3n4p95

Aeeni, M., Ahmadi, F., \& Shafei, R. (2013). Exploration Relationship Between Internal Marketing And Organizational Citizenship Behavior In Bank Of Kurdistan Province. Interdisciplinary Journal Of Contemporary Research In Business, 4(12), 850-859.

Al-Hawary, S. I., Al-Qudah, A. K., Abutayeh, M. P., Abutayeh, M. S., \& Al-Zyadat, D. Y. (2013). The Impact Of Internal Marketing On Employee's Job Satisfaction Of Commercial Banks In Jordan. Interdisciplinary Journal Of Contemporary Research In Business, 1-17.

Bartlettj, E., Kotrlik, J., \& Higgins, C. (2001). Organizational Research: Determining Appropriate Sample Size In Survey Research. Information Technology, Learning, And Performance Journal, 43-51.

Berry, L. (1981). The Employee As Customer. Journal Of Retail Banking, 1-28.

Berry, L. L., Hensel, J. S., \& Burke, M. C. (1976). Improving Retailer Capability For Effective Consumerism Response. Journal Of Retailing, 1-14.

Bigley, G. A., \& Steers, R. M. (2003). Motivation and work behavior. New York: McGraw-Hill/Irwin.

Conduit, J., \& Mavondo, F. T. (2001). How critical is internal customer orientation to market orientation?. Journal of Business Research, 51(1), 11-24. http://dx.doi.org/10.1016/S0148-2963 (99)00044-2

Deckop, J. R., Mangel, R., \& Cirka, C. C. (1999). Research notes. Getting more than you pay for: Organizational citizenship behavior and pay-for-performance plans. Academy of Management Journal, 42(4), 420-428. http://dx.doi.org/10.2307/257012 
Dirks, K. T., \& Ferrin, D. L. (2002). Trust in leadership: meta-analytic findings and implications for research and practice. Journal of Applied Psychology, 87(4), 611-628.

Eldeen, A. T., \& El-Said, O. A. (2011). Implementation Of Internal Marketing On A Sample Of Egyptian. Anatolia - An International Journal Of Tourism And Hospitality Research, 1-16. http://dx.doi.org/10.1037/0021-9010.87.4.611

Elsamen, A. A., \& Alshurideh, M. (2012). The Impact Of Internal Marketing On Internal Service Quality: A Case. International Journal Of Business And Management, 13.

Graham, H. T., \& Bennett, R. (1991). Human Resources Management. London: Pitman Publishing.

Herzberg, F. (1968). One more time: How do you motivate employees (pp. 46-57). Boston: Harvard Business Review.

Hogg, G., Carter, S., \& Dunne, A. (1988). Investing In People: Internal Marketing And Corporate Culture. Journal Of Marketing Management, 1-895. http://dx.doi.org/10.1362/026725798784867563

Jha, S. (2014). Transformational leadership and psychological empowerment: Determinants of organizational citizenship behavior. South Asian Journal of Global Business Research, 3(1), 18-35. http://dx.doi.org/10.1108/SAJGBR-04-2012-0036

Kim, S. (2006). Public service motivation and organizational citizenship behavior in Korea. International Journal of Manpower, 27(8), 722-740.

Lin, H. F. (2007). Effects of extrinsic and intrinsic motivation on employee knowledge sharing intentions. Journal of Information Science, 33(2), 135-149. http://dx.doi.org/10.1177/0165551506068174

Llyold, M. (2011). From Recruitment To Retirement. Internal Marketing, 1-5.

Locke, E. A., \& Latham, G. P. (2002). Building a practically useful theory of goal setting and task motivation: A 35-year odyssey. American Psychologist, 57(9), 705-717. http://dx.doi.org/10.1037//0003-066X.57.9.705

Mccoy, T. J., \& Associates. (2006). Empowerment. Problem Solver Series, 1-14.

Moorman, R. H., Blakely, G. L., \& Niehoff, B. P. (1998). Does perceived organizational support mediate the relationship between procedural justice and organizational citizenship behavior? Academy of Management Journal, 41(3), 351-357. http://dx.doi.org/10.2307/256913

Netemeyer, R. G., Bowles, J. S., Mackee, D. O., \& Mcmurrian, R. (1997). An Investigation Into The Antecedents Of Organizational Citizenship Behaviors In A Personal Selling Context. Journal Of Marketing, 1-98. http://dx.doi.org/10.2307/1251791

Niehoff, B. P., \& Moorman, R. H. (1993). Justice as a mediator of the relationship between methods of monitoring and organizational citizenship behavior. Academy of Management Journal, 36(3), 527-556. http://dx.doi.org/10.2307/256591

Organ, D. W. (1988). Organizational Citizenship Behavior: The Good Soldier Syndrome. Lexington: Lexington Books.

Organ, D. W., Podsakoff, P. M., \& Mackenzie, S. B. (2006). Organizational Citizenship Behavior: Its Nature, Antecedents, And Consequences. USA: 2006Sage Publications.

Podsakoff, P. M., Mackenzie, S. B., Paine, J. B., \& Bachrach, D. G. (2000). Organizational Citizenship Behaviors: A Critical Review Of The Theoretical And Empirical Literature And Suggestions For Future Research. Journal Of Management, 1-51. http://dx.doi.org/10.1016/S0149-2063(00)00047-7

Roshani, S., Enayati, G., \& Lashkari, M. (2013). The Investigation Of The Effects Of Internal Marketing On The Services Quality Emphasizing The Role Of Intermediate On Organizational Citizenship Behaviors (Case Study Of The Banks Of Esfarayen City). Interdisciplinary Journal Of Contemporary Research In Business, $1-10$.

Seyed, J. R., Rayej, H., Agamiri, A., \& Yazdani, H. (2010). Internal Marketing: A Step In To Improve Organizational Citizenship Behaviour And Service Quality. Modarres Olum Ensani, 1-98.

Shahin, A., Naftchali, J. S., \& Pool, J. K. (2014). Developing a Model for the Influence of Perceived Organizational Climate on Organizational Citizenship Behavior and Organizational Performance Based on Balanced Score Card. International Journal of Productivity and Performance Management, 63(3), 3-3. http://dx.doi.org/10.1108/IJPPM-03-2013-0044 
Sinčić, D., \& Vokić, N. P. (2007). Integrating Internal Communications,Human Resource Management Andmarketing Concepts Into The New Internal Marketing Philosophy. Croatia: University Of Zagreb.

Wieseke, J., Ahearne, M., Lam, S. K., \& Dick, R. V. (2009). The Role Of Leaders In Internal Marketing. Journal Of Marketing, March, 1-2. http://dx.doi.org/10.1509/jmkg.73.2.123

\section{Copyrights}

Copyright for this article is retained by the author(s), with first publication rights granted to the journal.

This is an open-access article distributed under the terms and conditions of the Creative Commons Attribution license (http://creativecommons.org/licenses/by/3.0/). 